YEARBOOK

of ANTITRUST

and REGULATORY

STUDIES

www.yars.wz.uw.edu.pl
Peer-reviewed scientific periodical, focusing on legal and economic issues of antitrust and regulation. Creative Commons Attribution-No Derivative Works 3.0 Poland License.



Centre for Antitrust and Regulatory Studies, University of Warsaw, Faculty of Management www.cars.wZ.uw.edu.pl

\title{
The Principle of Liability in Private Antitrust Enforcement in Selected European States in Light of the Implementation of the Damages Directive into the Polish Legal System
}

\author{
by
}

Dominik Wolski*

\section{CONTENTS}

I. Introductory issues

II. The interplay between EU and national laws

III. The principle of liability in private antitrust enforcement - the case of Poland

IV. The principle of liability in selected European states

1. United Kingdom

2. Germany

3. Netherlands

4. Austria

5. Italy

6. France

7. Lithuania

V. Principle of liability and the effectiveness of private antitrust enforcement

VI. Conclusions

\section{Abstract}

In the vast majority of European countries, private antitrust enforcement falls under general rules of civil law. One of the issues to be discussed in relation to this type of litigation is the principle of liability, which exists in the given legal system, and

* $\mathrm{PhD}$ in law, attorney-at-law, member of the Centre of Antitrust and Regulatory Studies at the Faculty of Management, University of Warsaw, lecturer at Katowice School of Economics; dominik.wolski@wolski-legal.com. Article received: 28 June 2016; accepted: 2 September 2016.

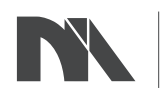

Ministry of Science and Higher Education

Republic of Poland
The creation of the English-language version of these publications is financed in the framework of contract No. 768/P-DUN/2016 by the Ministry of Science and Higher Education committed to activities aimed at the promotion of education. 
its presumed impact on private enforcement. This problem has been debated in the course of the implementation works on the Damages Directive into the Polish legal system. A discussion on the principle of liability has taken place at least twice in this context. First, the issue was considered by the Civil Law Codification Commission and expressed in its Assumptions behind the Draft Act on complaints for damages caused by the breach of competition law. Subsequently, the principle of liability was assessed again at the reconciliation conference held at the Ministry of Justice. This is but a part of a broader discussion about the relationship between the rule of liability existing in national laws being applied to private enforcement cases and EU law as well as limitations arising from the latter. After outlining this interplay, the paper will briefly introduce solutions adopted with respect to the principle of liability in the context of private enforcement in selected European countries. The selection is not random, despite the fact that a limited number of countries has been analysed - eight including Poland. These include the most advanced EU Member States when it comes to private antitrust enforcement (such as the UK, Germany or the Netherlands), along with less developed examples (such as Italy or France), and even underdeveloped countries when it comes to the number and popularity of private antitrust litigations (such as Lithuania and Poland). This sort of analysis paints a relatively comprehensive picture of the adopted solutions in relation to the principles of liability governing private enforcement cases in Europe. The same is true for the issue of the burden of proof and presumptions/binding power in civil proceedings of decisions issued by competition authorities. Furthermore, what seemed to be crucial for the drafters of the Damages Directive, this sort of analysis makes it possible to formulate certain conclusions with respect to the relationship between the effectiveness of private enforcement in a given State and the adopted principle of liability. The final conclusions understandably focus on the Polish example, that is, the implementation of the Damages Directive into the Polish legal system.

\section{Résumé}

Dans la grande majorité des pays européens l'application privée du droit de la concurrence relève des règles générales du droit civil. Un de problème qui exige l'analyse dans ce type de litige est le principe de la responsabilité qui existe dans le système juridique particulier, ainsi que son effet sur l'exécution privée du droit de la concurrence. Ce problème était discuté pendant les travaux concernant la transposition de la directive relative aux certaines règles régissant les actions en dommages («Damages Directive») dans le système juridique polonais. La discussion sur le principe de la responsabilité a eu lieu au moins deux fois dans ce contexte. Tout d'abord, la question a été examinée par la Commission de codification du droit civil et exprimée dans ses hypothèses concernant le projet de loi sur les actions en dommages pour les infractions aux dispositions du droit de la concurrence. Ensuite, le principe de la responsabilité a été évalué de nouveau lors de la conférence de réconciliation qui a eu lieu au Ministère de la Justice. C'est juste une partie de discussion plus large concernant la relation entre le principe de la responsabilité existant dans les législations nationales 
appliquées dans des affaires d'application privée du droit de la concurrence et le droit de l'Union européenne, ainsi que les limitations qui en découlent. Après la présentation cette interaction, le document parlera brièvement des solutions adoptées dans certains pays européens afin de répondre au problème du principe de la responsabilité dans le contexte de l'application privée du droit de la concurrence. La sélection n'est pas aléatoire, malgré le fait qu'un nombre limité de pays a été analysé - huit pays dont la Pologne. Elle inclus les Etats Membres de l'Union européenne les plus avances en ce qui concerne l'application privée du droit de la concurrence (comme le Royaume-Uni, l'Allemagne ou les Pays-Bas), ainsi que des exemples de juridictions moins développés (comme l'Italie ou la France) et même des pays sous-développés en ce qui concerne le nombre et la popularité des actions en dommages dans le domaine du droit de la concurrence (comme la Lituanie et la Pologne). Ce type d'analyse donne une vision relativement complète des solutions concernant les principes de responsabilité dans le domaine d'application privée du droit de la concurrence adoptées en Europe. C'est la même chose en ce qui concerne la question de la charge de la preuve et des présomptions/le pouvoir contraignant des décisions rendues par les autorités de la concurrence dans les procédures civiles. En outre, ce qui semblait crucial pour les rédacteurs de «amages Directive», ce type d'analyse permet de formuler certaines conclusions concernant la relation entre l'application privée du droit de la concurrence dans un État Membre particulier et le principe de responsabilité adopté dans cet État. Les conclusions finales se focalisent sur l'exemple polonais, c'est-à-dire sur la transposition de «amages Directive» dans le système juridique polonais.

Key words: private antitrust enforcement; litigations; principle of liability; burden of proof; presumptions; implementation; Damages Directive; effectiveness.

JEL: K13; K21; K42

\section{Introductory issues}

Private antitrust enforcement is often closer associated with antitrust enforcement as such, in its public dimension, than with private law and its principles. This realisation is not surprising seeing as antitrust enforcement was for many years clearly more public than private, maybe except the USA and its legacy. Even now, after the extensive efforts undertaken by the European Commission (hereinafter, EC) in order to trigger the private model of antitrust enforcement in Europe, the public pillar continues to remain the main form of EU competition policy. On the other hand, all the efforts exerted by EU institutions, including the Damages Directive ${ }^{1}$, should ultimately bring

1 Directive 2014/104/EU of the European Parliament and of the Council of 26 November 2014 on certain rules governing actions for damages under national law for infringements of 
about a noticeable, albeit maybe not spectacular, strengthening of private antitrust enforcement. This should be true for those EU Member States in particular where private enforcement is still underdeveloped, such as Poland for instance.

According to the Damages Directive, EU Member States must implement the Directive into their domestic legal systems not later than by 27 December 2016. Among the number of issues discussed in Poland during the legislative works undertaken in order to implement the Directive ${ }^{2}$, the principle of liability on which private antitrust enforcement should be based proved to be of consequence. The question that arises against the background of that discussion is - shall it be the principle of fault (fault-based liability) based on at least negligence (since an intentional act of a wrongdoer as an antitrust infringement is undisputable), or should a more rigorous type of liability like strict, objective or even an absolute liability apply (more about difference between strict liability - called in Polish law risk liability - and an absolute liability concept: Safjan, 2008, p. 1371). Indeed, the principle of liability to be introduced into future Polish legislation on private antitrust enforcement seemed to have been among the more pertinent issues being discussed during the preparations by the Civil Law Codification Commission of the Assumptions behind the Draft $\mathrm{Act}^{3}$ as well as at the meeting of the working group appointed by the Ministry of Justice (the so-called reconciliation conference) ${ }^{4}$.

The significance of that discussion emerges from the main aim of the Damages Directive, that is, a more effective private antitrust enforcement in EU Member States 5 . As a result, a key question arises here about the relationship between the effectiveness of private antitrust enforcement and the principle of liability. This discussion is also present with respect to the relationship between the concept of liability for an EU competition law infringement and the legal framework of liability applicable to private antitrust enforcement cases being brought before courts in EU Member States (Havu, 2014; Jones, 2016; Monti, 2001). It is justifiable to say that one of the ways to answer that question is to analyse solutions applied in several EU countries,

the competition law provisions of the Member States and of the European Union, OJ L 349, 05.12.2014, p. 1 (hereinafter, Damages Directive).

2 See footnote 3 and 4.

3 The Civil Law Codification Commission (hereinafter, Codification Commission) prepared Assumptions behind the Draft of the Act on complaints for damages caused by the breach of competition law of 1 December 2015, hereinafter, the Assumptions behind the Draft of the Act (draft is accessible at: https://bip.ms.gov.pl/pl/dzialalnosc/komisje-kodyfikacyjne/komisjakodyfikacyjna-prawa-cywilnego, accessed 02.09.2016).

4 The conference held $18^{\text {th }}$ April 2016 at the Ministry of Justice. For more information about the consultation process see: http://legislacja.rcl.gov.pl/projekt/12283303 (accessed 02.09.2016).

${ }^{5}$ See motive 4 of the Damages Directive. 
in particular those where private enforcement plays a significant role. On this basis, it is necessary to formulate some conclusions on the subject of the interplay between such solutions and the effectiveness of the private model of antitrust enforcement in those Member States. A wide range of solutions exists when it comes to the principle of liability in private antitrust enforcement in national legal systems of European and non-European countries. However, this is not only a question about the principle as such. It also relates to the issue of the burden of proof as well as to presumptions/binding force of the decisions issued by competition authorities. The latter plays a crucial role in follow-on claims and can significantly affect the shape of the principle of liability and its practical application.

Bearing in mind the aforementioned factors, the aim of this article is to first specify what type of solutions have been applied in selected European states. The methodological decision has been taken to not only analyse countries where private enforcement is well developed, but also those with a mid- or underdeveloped private model of antitrust enforcement as well. On this basis, the following analysis should not only facilitate a proper implementation of the Damages Directive in Poland, but be also useful to judges and legal practitioners who will soon face the need to use the new law in practice. It is worth stressing that Polish judges will very often be facing this challenge for the very first time in their professional life. Sharing practical experiences from private antitrust litigations in other countries, in particular more advanced ones, is particularly important for Poland. This is so because in light of the current version of the Assumptions behind the Draft Act, private enforcement cases will not be dealt with by a specialized judiciary but by ordinary, district courts.

As mentioned, the methodological decision has been taken to analyse models existing in several European States. For obvious reasons, the outcome of this analysis is based on the legal status before the implementation of the Damages Directive. Having said that, in some countries, the UK in particular, the adopted solutions applicable to private antitrust enforcement are further reaching than those in the Directive ${ }^{6}$. Thus, what selection criteria have been used to choose which countries to analyse in this article? Poland has obviously been chosen because of the Damages Directive's implementation context,

${ }^{6}$ Department for Business, Innovations and Skills, Consultation: Implementing the EU Directive on damages for breach of competition law, January 2016. Retrieved from: https://www. gov.uk/government/uploads/system/uploads/attachment_data/file/495757/BIS-16-6-consultationimplementing-the-EU-directive-on-damages-for-breaches-of-competition-law.pdf (02.09.2016); Slaughter and May, Private enforcement of competition law in the UK, October 2015. Retrieved from: https://www.slaughterandmay.com/what-we-do/publications-and-seminars/publications/ client-publications-and-articles/p/private-enforcement-of-competition-law-in-the-uk/ (02.09.2016). 
especially because this particular issue appeared in the legislative works before both the Codification Commission and the working group appointed by the Ministry of Justice. The UK, Germany, the Netherlands and Austria were selected because private antitrust litigations are more developed there than in the rest of Europe (Jones, 2016, p. 4). Italy and France are examples of countries where private antitrust enforcement is relatively developed, but not as much as in the most advanced States. Lithuania is a country where the private enforcement model seems to be not yet developed enough, however its legal framework does not differ significantly from that found in Italy or France for instance. The aforementioned selection might not paint a full picture of private antitrust enforcement on the global scale (it does not include States with the biggest world economies like the USA, Japan, China or India). Yet it does make it possible to get a general idea, and sometimes a more detailed notion of the solutions applied with respect to the principle of liability in the biggest European States.

Last but not least, mentioned in this introduction must be the limitations placed on this analysis. Like the Damages Directive, this article mainly focuses on tortious liability in the context of damages complaints, with some references to contractual liability and other remedies like invalidity of contracts or unjust enrichment. The article focuses primarily on business-to-business antitrust actions (i.e. class-actions are not mentioned) albeit to some extent the issues discussed therein are of general nature, being applicable to consumer claims based on antitrust infringements also. Moreover, a look at the principles and other elements of civil liability in particular States (burden of proof, presumptions, etc.) has a general, illustrative nature. This is satisfactory for the purposes of this article but profound understanding of such liability doubtlessly requires a further, in-depth analysis. The latter goes beyond the aim and scope of this paper.

\section{The interplay between EU and national laws}

As mentioned above, the principle of liability in private enforcement cases is but one part of a wider discussion taking place against the background of the principle of efficiency in the private model of antitrust enforcement in EU Member States. Even if national private law is of primary relevance in damages actions, it must stay within the limits of acceptability set by European law. As a result, the question appears on the compatibility with EU law of national rules concerning liability being applied to private enforcement cases (Havu, 2014, p. 5-6). One of the issues discussed in this context is whether 
liability for EU competition law infringements before Member States' courts should be based on negligent or intentional violations, or whether it should be shaped as more restrictive liability, that is, strict, objective or even an absolute one. This problem entails another question about possible limitations on the concept of liability in national law arising from EU competition law and caselaw. Thus the issue here is how to frame national law on private enforcement of EU competition law (Jones, 2014, p. 14) as well as the applicability of fault in private enforcement actions based on infringements of EU law.

Yet EU law does not contain any rules on liability or guidelines on private antitrust enforcement, not to mentioned on the concept of fault (with some exceptions in the Damages Directive, see Havu, 2014, p. 8). The conclusions drawn from that fact vary considerably. Some commentators go as far as to say that the lack of fault as a condition for compensation in EU law must mean that there is no fault requirement at all, which means strict liability should be applied (ibidem). This means, in turn, that national law should not require such a condition (fault) either. This finding seems to be at least debatable. EU law focuses more on facilitating the possibility for private antitrust enforcement in Member States, with emphasis on procedures (Monti, 2001, p. 5), than on particular rules on liability. Moreover, it is worth mentioning that even if EU law, or EU case-law, deals to some extent with notions such as negligence or intentional act of a wrongdoer, they appear in quite a different context than liability based on private law. When it comes to an infringement of EU competition law, negligent infringement, as opposed to an intentional act of a wrongdoer, have been analysed in the context of the imposition of fines ${ }^{7}$. In turn being unaware of the law, as scrutinized in Schenker ${ }^{8}$, cannot matter in private enforcement of national rules at all, for the simple reason that legal ignorance would have never been taken into consideration as a reason for escaping liability. Moreover, as the Polish Supreme Court stated in one of its rulings, an undertaking's due care encompasses knowing the law and its consequences within the scope of its business activity ${ }^{9}$. As a result, neither EU competition law or case law nor the Damages Directive include any notion of fault (be it negligent or intentional) addressed to national laws being developed as legal frameworks for private antitrust enforcement. Effectiveness of private enforcement is the only requirement included in this context, which cannot

7 See opinion of AG Mayras in Case 26/75 General Motors Continental NV, ECLI:EU:C:1975:150, as well as how the intentional act was considered by the GC in case T-66/92 Herlitz $A G$ v. Commission, ECLI:EU:T:1994:84.

8 Case C-681/11 Bundeswettbewerbsbehörde and Bundeskartellanwalt v. Schenker \& Co. AG and others, ECLI:EU:C:2013:404.

9 See judgment of the Supreme Court of 17 August 1993, III CRN 77/93, OSN 1994, No. 3 , sec. 69 . 
be limited to any extent by national rules. In other words, the principles of efficiency and equivalence are the main limits on the acceptability of national law in damages cases based on an infringement of EU competition law (Havu, 2014, p. 10).

Having said that, it has to be emphasized that there are still significant divergences in national rules on private enforcement, the principle of liability and the concept of fault (Jones, 2016, p. 20). It is also clear that such rules should comply with the principle of effectiveness which accompanied the drafters of the Damages Directive. Nevertheless, despite the aforementioned divergences in Member States, there is no reason to conclude that the requirement of fault that exists in the laws of several European countries in relation to their private antitrust enforcement cases would be incompatible with EU law. This is particularly obvious in cartel cases where an antitrust infringement is evidently intentional. As such, the requirement of fault to any extent cannot prevent private enforcement claims from being successful (Havu, 2014, p. 11, 22). This was probably the reason why the Damages Directive does not contain any rules regarding the principle of liability, other than that national law must follow the principles of effectiveness and equivalence. However, the discussion is still underway. It cannot be excluded that in the case of an infringement of EU competition law being enforced before a national court in a private action, a specific notion of fault or even strict or objective liability will be created and applied in the future (for more about the possible scenarios of EU law and national law developments as well as case-law see Havu, 2014, p. 12).

\section{The principle of liability in private antitrust enforcement - the case of Poland}

The Damages Directive does not impose a specific solution on Member States regarding the principle of liability on which private antitrust litigations should be based. According to motive 11 of its preamble, any adopted solution must however observe the principles of effectiveness and equivalence. There is a consequence of the main goal of the Damages Directive, that is, to strengthen private antitrust enforcement in EU Member States. Thus the aforementioned freedom of choice is limited and must respect those principles. For that reason, the issue of the principle of liability to be applied in Poland's future legislation on private antitrust enforcement has been widely discussed by the Codification Commission. Not without doubts, members of the Commission had adopted in the first version of the Assumptions behind the Draft Act a kind of objective liability, based on a breach of competition law that had no reference to fault, 
neither intentional nor one committed negligently. As a result, an entity that breached competition law - except specified justifications such as acting on the basis of an act issued by an authority or court - would have been liable even if no form of negligence had occurred ${ }^{10}$. This kind of liability seemed even more restrictive than strict liability, in other words, a type of absolute or more precise than objective liability. This solution created doubts in particular in more complex cases, where an objective antitrust violation occurred in the market not necessarily meaning that all entities (businesses) involved in the given practice - consciously or unconsciously - have actually been acting contrary to competition law (Wolski, 2016, p. 41-44).

These doubts ultimately resulted in a shift in the approach of the Codification Commission towards the principle of liability. After discussions that took place at the meeting of the reconciliation conference held at the Ministry of Justice on 18th April 2016, it has been decided that the future Polish Act on private antitrust enforcement should, in fact, apply the principle of fault. Nevertheless, in order to be maximise compliance with the main aim of the Damages Directive, in particular with its motive 11, this principle should be accompanied by the presumption of fault. Thus, the burden of proof to the contrary should rest upon the defendant. As a result, the latter is not liable if it was proven that any form of negligence, even ordinary negligence, has not occurred. This brings about a situation when even if based on negligence, this solution meets the Directive's expectations in relation to measures aimed at ensuring the effectiveness of private antitrust enforcement in Member States. Moreover, it seems to be fully compliant with EU law requirements discussed above.

Based on said assumption, but bearing in mind that the final shape of the future act is still under consideration, it is worth knowing what kind of solutions exist in the laws of other European countries in this respect. This is even more interesting from the perspective of pending legislative works and arguments presented by the Codification Commission for the application of objective liability that have made reference to similar solutions adopted in other Member States ${ }^{11}$. This research encompassing selected European countries may produce a set of conclusions which can be useful not only in the implementation process of the Damages Directive but for future legal practice too. To this extent, the distinction between objective liability and fault-based liability is important, in particular in stand-alone cases, which are not preceded by decisions issued by a competition authority acknowledging an antitrust

10 See current version Assumptions behind the Draft of the Act of $7^{\text {th }}$ March 2016, p. 8 (retrieved from: http://legislacja.rcl.gov.pl/ projekt/12283303/katalog/12341840\#12341840, accessed 02.09.2016).

11 Assumptions behind the Draft of the Act of $7^{\text {th }}$ March 2016, p. 8. 
violation. In the latter case, it is enough from a plaintiff's perspective to evoke that the antitrust breach has occurred and that the defendant was involved therein. Based on objective liability, the defendant is not able to successfully argue that there was no element of his negligence in such a breach. On the contrary, in the event of liability based on fault, the burden of proof will be on the defendant to show that there was no negligence on his part in the infringement. If the defendant fails to do so, taking into consideration the examination of evidences conducted by the court according to civil procedure, the defendant's antitrust infringement will be established. It is worth mentioning that in Polish civil law even the smallest degree of negligence entails liability based on either Article 415 (constitutes tort liability) or Article 471 of the Civil Code $^{12}$ (the basis of contractual liability). The Civil Code sets out in Article 355 $\S 2$ a professional standard of due care in relation to activities being conducted by undertakings, which has been mentioned above in relation to the duty to know the law. In follow-on cases, it thus seems to be almost impossible for a company to prove that there was not even the smallest lack of due care (negligence) in the antitrust infringement in question. Thus the effectiveness of private antitrust enforcement has not been threatened to any extent.

In cases not preceded by a decision of a competition authority the situation is far more "complex". The breach of competition law is not acknowledged in an infringement decision and the aforementioned possibility of proving that the defendant has been acting with due care is therefore more probable. The court in turn, not using any findings arising from such a decision, must on its own consider if any negligence has occurred. If liability is based on a rebuttable presumption of fault of the defendant, the latter from the very outset of the proceedings - if he wants to cause a dismissal of the plaintiff's complaint - must prove that he has been acting with due care within the meaning of Article $355 \S 2$ of the Civil Code. If the defendant succeeds, he is not found liable for an antitrust infringement to any extent whatsoever neither based on tort law nor on the contractual regime. Otherwise, with no prejudice for the two remaining conditions of liability, namely damage and causation, the defendant is considered liable for damages suffered from the infringement in question. It thus turns out that not only the principle of liability but also the burden of proof and presumptions play a considerable role in successful antitrust litigations (for more information about legal grounds of private antitrust enforcement in Poland see i.a.: Jurkowska, 2008, p. 64-67; Stefanicki, 2014, p. 199-151).

12 The Civil Code of 23 April 1964 (consolidated text Journal of Laws 2016, item 380 as amended), hereinafter, the CC. 


\section{The principle of liability in selected European states}

\section{United Kingdom}

The UK example is worthy of attention for many reasons. First of all, it goes without saying that private antitrust enforcement in Britain is among the most advanced and developed in Europe (Jones, 2016, p. 4) ${ }^{13}$. As early as 1984, English courts acknowledged in Garden Cottage ${ }^{14}$ (Clough and McDougall, 2004 , p. 1) that damages should be available for an affected party in case of a breach of EU competition law. Furthermore, following the Enterprise Act 200215, which somewhat amended the Competition Act of $1998^{16}$, the Competition Appeal Tribunal in London (hereinafter, CAT) was created as a specialized court to award damages in follow-on cases preceded by decisions of the National Competition Authority (hereinafter, NCA) or the EC. It is worth mentioning that despite some divergences between the legal systems and courts of England, Scotland, Northern England and Wales, British competition law, in particular the Competition Act as well as the jurisdiction of the CAT, apply throughout the UK. It is thus not by chance that one of the most important private antitrust enforcement cases finally decided by the European Court of Justice - the Crehan case - originates from the UK (the Crehan case was analysed in detail: Waterson, 2010; see also: Clough and McDougall, 2004, p. 1-2). As a result, a significant number of damages actions based on antitrust infringements are brought before British courts, the High Court and the CAT. Indeed, parties often choose the UK as their global litigation hub ${ }^{17}$. It is also worth mentioning that the CAT has a more commercial and less legalistic approach ${ }^{18}$.

Within the British legal framework, actions for damages arising from the infringement of EU competition law fall under the tort regime as a breach of statutory duty (Clough and McDougall, 2004, p. 2). Furthermore, even if a contractual relationship exists between the claimant and the defendant, claims of cartel victims in British law tend to be qualified as claims in tort rather than in contract (ibidem, p. 26). Domestic cases are based on the Competition Act of 1998 and are treated as a breach of statutory duty. Furthermore, according

3 See also Department for Business, Innovations and Skills, supra note 6, at p. 3.

14 Garden Cottage Foods Ltd v. Milk Marketing Board (1983) HL, 23/4/83. See also Slaughter and May, supra note 6, at p. 1.

15 Retrieved from: http://www.legislation.gov.uk/ukpga/2002/40/contents (02.09.2016).

16 Retrieved from: http://www.legislation.gov.uk/ukpga/1998/41/contents (02.09.2016).

17 Slaughter and May, supra note 6, at p. 9.

18 Ibidem, p. 5. 
to Section 47A of the Competition Act, the CAT is bound since 2002 by an infringement decision issued under either British or EU competition law ${ }^{19}$. With respect to the principles of liability, to bring a claim successfully, the claimant should provide evidence that the aforementioned breach of statutory duty based either on EU or British law has occurred. However, there is no requirement of fault in the case law, but only a breach of relevant competition law rules. This means, in turn, that strict liability is applicable under British law in antitrust enforcement (Clough and McDougall, 2004, p. 9-10). The infringing party's conduct can be scrutinized by the court when the plaintiff's claim includes exemplary damages, which in very specific circumstances are available under British law (inter alia when the defendant acted intentionally to harm the plaintiff (ibidem, p. 25-26) ${ }^{20}$.

In terms of the burden of proof of the infringement in question, as mentioned above, it rests on the claimant. A normal civil standard applies with respect to the standard of proof, that is, the balance of probabilities (Clough and McDougall, 2004, p. 9-12) ${ }^{21}$. However, decisions of the UK competition authority and the EC are binding before the CAT according to Section 47A of the Competition Act since 2002 when the Enterprise Act came into force. Decisions of the UK competition authority are also binding in ordinary courts according to Section 58A of the Competition Act. As the competition authority will have already proved that competition law had been breached, the claimant can rely on such decisions as proof of that infringement ${ }^{22}$. According to rulings of the Court of Appeal and the CAT, this means, in turn, that in follow-on cases, "the Tribunal's jurisdiction in a follow-on claim is limited to questions of causation and quantum (quantification of loss)"23. Hence in the latter cases, the principle of liability plays a merely symbolic role, regardless of what would have been strict or fault-based liability, because the infringement was already confirmed in the infringement decision issued by the competition authority. Nonetheless, under the British tort law regime, strict liability is applicable in private antitrust enforcement cases, instead of liability based on fault.

19 See also Department for Business, Innovations and Skills, supra note 6, at p. 8 and reasoning of judgments mentioned in footnote 23 .

20 See also reasoning of judgments mentioned in footnote 23.

21 The finding is more likely than not.

22 See Department for Business, Innovations and Skills, supra note 6, at p. 8.

23 See e.g.: Case No. 1166/5/7/10, Albion Water Ltd. v. DWR Cymru Cyfyngedig (the CAT), Case No. C3/2011/1995, Deutsche Bahn AG \& Ors v. Morgan Crucible Co PLC \& Ors (the Court of Appeal) and Case No. C3/2010/0404, Enron Coal Services Ltd. v. English Welsh \& Scottish Rail Ltd. (the Court of Appeal). 


\section{Germany}

A number of interesting developments has taken place with respect to private antitrust enforcement in Germany. Although they were rather undermined (supposedly in order to strengthen the effect of the regulatory gap) in the EC's working papers preceding the Damages Directive, they seem quite significant. $\mathrm{S}$. Peyer even says that "[t]he debate about the private rights to action is based on the assumption that private enforcement is completely underdeveloped in Europe" (Peyer, 2010, p. 6) ${ }^{24}$. According to the report drafted by the German Federal Cartel Office (Bundeskartellamt) in 2005, German courts registered approximately 900 private enforcement cases between 2002 and 2005. Importantly, this number contained not only follow-on damages claims but also a significant amount of stand-alone cases (Buntscheck and Stichweh, 2015 , p. 154 $)^{25}$. The legal framework for private antitrust actions derives from the 1958 German Act Against Restrains of Competition (hereinafter, ARC), particularly from the $7^{\text {th }}$ Amendment to this Act which came into force on 1 January 2005. This reform was meant to facilitate and improve the legal environment for private antitrust enforcement actions (Peyer, 2010, p. 9; Wach, Epping, Zinsmeister and Bonacker, 2004, p. 1). Following this amendments, all private enforcement actions in Germany, regardless of whether based on breaches of EU or German competition law, are submitted on the basis of Section 33(3) ARC. Moreover, Section 33(4) ARC stipulates that the court shall be bound by a final decision of the NCA, the EC, or the NCA of another EU Member State declaring that an infringement had occurred.

Unlike the UK, German civil law requires fault in relation to the antitrust violation. Fault in turn means that a person acts intentionally or negligently, namely he/she fails to observe his/her duty of due care, albeit even slight negligence is sufficient. Moreover, if the infringement of competition law has been proven, then it is upon the defendant to prove the absence of negligence. Thus the burden of proof that a person has fulfilled his/her duty of reasonable care is shifted to the defendant. Nevertheless, the court must be convinced that the facts presented by the plaintiff are true. This does not mean absolute

24 The opinion of the author has to be supported, in particular in relation to some European countries; it does not seem to be true, in particular at the time when the Damages Directive was released, namely 2013.

25 See also Bundeskartellamt, Private Kartellrechtsdurchsetzung - Stand, Probleme, Perspektiven: Diskussionpapier für die Sitzung des Arbeitskreises Kartellrecht am 26 September 2005 (retrieved from: http://www.bundeskartellamt.de/SharedDocs/Publikation/DE/Diskussions _ Hintergrundpapier/Bundeskartellamt $\% 20-\% 20$ Private $\% 20$ Kartellrechtsdurchsetzung.pdf? blob $=$ publicationFile $\& v=4,02.09 .2016$ ). 
certainty on the side of the court - yet a high level of plausibility is required, that is, beyond reasonable doubt (Buntscheck and Stichweh, 2015, p. 155). Similarly, there is a rebuttable presumption of fault in cases based on a breach of contract (Wach, Epping, Zinsmeister and Bonacker, 2004, p. 9-10). The standard of proof here requires a high level of plausibility (this requires that plausibility shall prevail over remaining doubts but without excluding them fully; ibidem, p. 11). German courts referred also to prima facie evidences in several cartel cases. This means that the fact in question (e.g. higher prices or the fact that some undertaking has been affected by the cartel agreement) can be assumed based on other facts and in connection with certain experiences (Kuijpers, Tuinenga, Wiskin, Dietzel, Campbell and Fritzsche, 2015, p. 8 ). With regard to the latter, it is worth mentioning that claims related to antitrust infringements do not necessarily have to be pursued in order to obtain compensation. A significant number of cases exist in Germany that are being pursued with the objective to nullify a contract on the basis of an antitrust violation. Once the court declares a contract as null and void, the plaintiff demands to recover unjust enrichment from the defendant based on German civil law. It thus turns out that contrary to common opinion, damages claims constitute only one part of private antitrust enforcement (Peyer, 2010, p. 48).

\section{Netherlands}

Private enforcement is not as developed in the Netherlands as it is in the UK. However, Holland is often mentioned as a place with a relatively advanced private antitrust enforcement model, unlike many other EU Member States (Kuijpers, Tuinenga, Wiskin, Dietzel, Campbell and Fritzsche, 2015, p. 1). Moreover, a number of private enforcement cases are being considered by Dutch courts. By contrast, merely a few years ago, the opinion about the popularity of private enforcement in the Netherlands was quite different (VerLoren van Themaat, Hettema and Buruma, 2004, p. 1) ${ }^{26}$. This could mean that Holland has come a long way in the last few years when it comes to antitrust litigation. It turns out that there is a rage of antitrust enforcement types in Holland nowadays, similarly to Germany, not only those that seek damages (damages claims), but also actions pertaining to the nullity of contracts or obtaining interim relief against antitrust violations too (ibidem, p. 1-2; Leeflang and Kuijper, 2013, p. 94).

${ }^{26}$ As the report even says: "Private litigation under antitrust rules was uncommon", ibidem. 
There are neither specific laws nor particular proceedings for private antitrust litigations in the Netherlands. Relevant legal ground can be found in EU competition law or Dutch competition law in conjunction with Dutch civil law. To this extent, there is no distinction between EU competition rules and national provisions (VerLoren van Themaat, Hettema and Buruma, 2004, p. 2). Antitrust damages actions are based on tort law - specifically Article 6:162 of the Dutch Civil Code. Nonetheless, antitrust litigations can also include an action for unjust enrichment (Article 6:212 of the Dutch Civil Code) or undue payment (Article 6:203 of the Dutch Civil Code). There are five basic conditions to be fulfilled for a plaintiff to be awarded damages. The conditions are as follows: "an unlawful act, attribution of the unlawful act to the wrongdoer, damages, and causality between unlawful act and the damages" (Leeflang and Kuijper, 2013, p. 94). While the breach of competition law is considered an unlawful act, an antitrust violation should be attributable to the economic entity infringing competition law (ibidem). Dutch tort liability is based on fault, which is interpreted broadly and includes objective criteria. This means that to acknowledge fault in civil proceedings neither bad faith nor intentional act is required (VerLoren van Themaat, Hettema and Buruma, 2004, p. 5). As a consequence, an antitrust violation entails "automatically" fault and negligence cannot be taken into consideration as a reason of a successful defence. However, that "strong" picture of civil liability of a person infringing competition law can be alleviated by the burden of proof of the facts constituting the violation, which rests on the plaintiff. In order to succeed, the claimant must thus provide relevant economic facts and circumstances of the breach (ibidem, p. 5-6; Kuijpers, Tuinenga, Wiskin, Dietzel, Campbell and Fritzsche, 2015, p. 10; Leeflang and Kuijper, 2013, p. 96). The evidence must be convincing and the unlawful act must be attributable to the defendant (ibidem, p. 96).

Bearing in mind those circumstances, it must be said that despite the fact that Dutch civil law almost "automatically" considers an antitrust violation as an unlawful act, and negligence cannot serve as a defence, objective criteria constituting fault must be satisfied. However, an unlawful act must be attributable to the defendant if the plaintiff is to succeed. The Dutch example shows that the fulfilment of such criteria in an antitrust litigation is feasible even in stand-alone cases. Suffice to mention here the European Merchant Services B.V. v. Equens S.E. case $^{27}$.

27 Midden Nederland District Court, 30.12.2013 (court's ruling available at: http://uitspraken. rechtspraak.nl/inziendocument?id=ECLI: NL:RBMNE:2013:7536, 02.09.2016). 


\section{Austria}

Austria is another EU Member State with an appreciable private antitrust enforcement. The national judiciary has dealt with several damages cases ${ }^{28}$, some of which were adjudicated by the Court of Justice of the European Union. These included Kone (umbrella pricing effect) ${ }^{29}$ or Donau Chemie (access to files) $^{30}$. Private enforcement in Austria has thus not only a relatively long tradition, but experienced significant developments in recent years (Elsner, Zandler and Kos, 2016, p. 49; Neumayr and Ablasser-Neuhuber, 2016). From $1^{\text {st }}$ March 2013, Section 37a(1) of the Cartel Act stipulates that a claimant may seek damages from parties culpably violating the substantive provisions of Austrian or EU competition law, being the legal grounds for private antitrust litigations. Moreover, according to Section 37a(3) of the Cartel Act, a decision of the cartel court, the EC or a NCA of another Member States acknowledging the infringement is binding for Austrian civil courts with respect to the illegality and culpability. In follow-on cases, the plaintiff must, to succeed, only provide evidence of the damage suffered and causality between the infringement and the damage. Section 37a(3) of the Cartel Act provides therefore an exemption from the culpability condition which is normally required by Austrian tort law. Nevertheless, that relief is only accessible for the plaintiff if the antitrust violation occurred after 1 March 2013, that is, when the aforementioned section came into force (Elsner, Zandler and Kos, 2016, p. 50-51). By contrast, according to Section $37 \mathrm{a}(1)$ of the Cartel Act, evidence of culpability should be provided by the plaintiff for stand-alone cases. Here, the case is based on Section 37a(1) of the Cartel Act but in conjunction with general civil law principles without facilitation given by Section $37 \mathrm{a}(3)$ of the Cartel Act (Neumayr and Ablasser-Neuhuber, 2016).

The burden of proof rests on the plaintiff. Hence the latter should provide evidences for the infringement (with reservations for Section 37a(3) of the Cartel Act), the damage suffered, and the causal link between the infringement and the damage. The standard of proof applicable is a high degree of probability (Wollmann and Prisker, 2004, p. 8). This is to say that as a rule, according to Section 37a(1) of the Cartel Act as well as Section 1294 of the Austrian Civil Code (the latter with respect to the legal framework before 1 March 2013), the infringement of competition law implies fault (ibidem, p. 7). The burden of proof that the defendant's act did not, in fact,

\footnotetext{
28 E.g. Elevators and Escalators cartel, OGH, 08.10.2008, 16 Ok 5/08.

29 Case C-577/12 Kone and others v. OBB Infrastruktur AG, ECLI:EU:C:2014:1317.

30 Case C-536/11 Bundeswettbewerbsbehorde v. Donau Chemie and Others, ECLI:EU:C:2013:366.
} 
imply fault rests on the very defendant (Neumayr and Ablasser-Neuhuber, 2016). Nevertheless, for the time being, this rule can play an important role only in stand-alone cases seeing as in follow-on cases (preceded by a decision of the authorities indicated in Section 37a(3) of Cartel Act) the defendant cannot challenge the antitrust violation found in such decisions by any means (ibidem). In some cases, the rules governing the standard of proof can be alleviated by the concept of prima facie evidence well established in Austrian civil procedure (Wollmann and Prisker, 2004, p. 7).

\section{Italy}

Italy is not a country traditionally associated with the intense development of private antitrust enforcement. It is therefore interesting to find out how that development looks in reality. By contrast to common opinion, "[p]rivate antitrust litigation in Italy is significant and increasing (...)" (Siragusa, D'Ostuni and Rizza, 2014, p. 79). This, at first glance, surprising statement is confirmed by the number and variety of cases brought before Italian courts which vary greatly and involve telecom operators, cheese, travel agencies, software, gas operators, phone service providers and airport security services (ibidem, p. 80).

There is no specific legal ground for private antitrust actions in Italy and so the applicable general legal basis is that of Italian civil law and proceedings. Violations of both Italian (Law 287/90) and EU competition law are primarily classified as torts but contractual liability for this type of infringements is also quite common. By contrast, complaints based on infringements of competition law regarding merger control are very unlikely. Section 2043 of the Civil Code is applicable as regards tort law; Section 1372 of the Civil Code constitutes the legal basis for contractual liability for private antitrust enforcement actions (ibidem, p. 79-80; Tardella and Maggiore, 2004, p. 1-3). In the vast majority of cases, plaintiffs brought actions pursuing damages or the nullity of a contract. Actions for damages are governed by general rules of civil law (the Civil Code), mainly those based on torts, but to some extent on the contractual regime too. Liability arising from antitrust infringements is primary considered as tort (ibidem, p. 2). Civil liability is based on fault. In the tort based regime, the plaintiff must prove the defendant's fault. As a result, in damages actions the plaintiff must prove that the antitrust infringement has been committed at least negligently. He must also prove the damage and the causal link between the infringement and damage suffered (Siragusa, D'Ostuni and Rizza, 2014, p. 80). According to Section 2697 of the Civil Code, the burden of proof as regards all the above conditions of tort liability rests on the plaintiff apart 
from fault, which does not need to be proven by the plaintiff (Tardella and Maggiore, 2004, p. 1-3, 14).

The aforementioned rules can be alleviated in follow-on cases. Despite the fact that decisions issued by a competition authority as well as those issued by administrative courts are not binding in antitrust litigations, they can have a significant impact on the result of such proceedings. This is because the Court of Cassation adjudicated that "the Authorities' and the administrative courts' findings have value as a preferred means of proof of the infringing conduct (i.e. they create a rebuttable presumption with respect to the existence of the infringement)" (Siragusa, D'Ostuni and Rizza, 2014, p. 83) ) $^{31}$. In such circumstances, the defendant should provide evidences that the behaviour in question has not been unfavourably assessed by the authority. Moreover, in one of the cases not only the authority's decision but even the statement of objections issued by the competition authority had evidential value (ibidem) ${ }^{32}$. This means that to assess how in the given legal system private antitrust enforcement works, all civil law rules and case-law developments have to be taken into consideration, mainly the principle of liability, the burden of proof as well as presumptions. The case law very often moderates these principles too. This leads to the softening of evidential rules in antitrust litigations in favour of the complainant.

\section{France}

Like Italy, France is rarely perceived as a country with a well-developed private antitrust enforcement but this situation has recently been changing (Lenoir, Plankensteiner and Truffier, 2015, p. 127). It is worth mentioning that as early as 1982, the French Constitutional Court has accepted the right to compensation in relation to legal breaches as a principle of constitutional value (ibidem $)^{33}$. As a result, while France is still behind the UK, the Netherlands or Germany in the number of private antitrust litigations, infringers became aware that antitrust breaches may result not only in administrative sanctions imposed by the NCA but private damages actions too. The number of the latter cases continues to increase (ibidem, p. 127).

The French approach to the legal grounds of private antitrust actions is based on traditional civil law principles (Thill-Tayara and Giner Asins, 2015, p. 169). There are therefore Articles L.420-1 and L.420-2 of the French Commercial

31 It refers to the ruling of the Court of Cassation, No. 3640/2009.

32 This time with reference to the Tribunale Milano of 10.11.2011.

33 See also: decision of the Constitutional Tribunal No. 82-144 DC of 22.10. 1982; decision No. 2010-2 on a preliminary ruling on constitutionality of 11.06.2010. 
Code (antitrust law) or EU competition law with reference to French tort law (Articles 1382 and 1383 of the Civil Code) or contract law (Article 1147 of the Civil Code) (Lenoir, Plankensteiner and Truffier, 2015, p. 127). To succeed, the plaintiff must prove the antitrust infringement committed by the defendant, the damage suffered and the causal link between the infringement and the damage (Thill-Tayara and Giner Asins, 2015, p. 169). Furthermore, the infringement must include fault. As a result, the claimant bears the burden of proof as to all of these conditions of liability, fault included.

Decisions issued by competition authorities do not have binding force in private litigations. This conservative approach is recently changing in the case law as courts are drawing more attention to the decisions issued by competition authorities by considering that an antitrust infringement constitutes "fault" (ibidem, p. 170; Lenoir, Plankensteiner and Truffier, 2015, p. 128). As early as 2010, the Supreme Court confirmed that a breach of competition law (anti-competitive behaviour) found by the competition authorities constitutes "fault" and a victim of that behaviour is entitled to claim damages ${ }^{34}$. In another judgment, the Supreme Court also specified that it is not sufficient to establish fault by mere reference to an infringement decision, without any description of the behaviour concerned (Thill-Tayara and Giner Asins, 2015, p. 178) ${ }^{35}$. However, it is worth noting that the judiciary's approach becomes increasingly pragmatic and it is more willing to grant damages in cases based on antitrust infringements (ibidem, p. 169). An EC decision is binding on national courts on the basis of Regulation $1 / 2003^{36}$. In spite of that, decisions of competition authorities, both national and foreign, do not have such binding force, but as mentioned above, they have high probative value (ibidem, p. 178). This approach has great importance in follow-on claims which are the most frequent way of private antitrust complaints in France. In stand-alone cases however, the burden of proof rests on the claimant. This means that to successfully bring an action before a court, a claimant must provide evidences of the antitrust infringement including fault. However, in practice sometimes courts even in stand-alone cases ask the competition authority for advice on the subject of the anti-competitive conduct (e.g. abuse of dominant position) or contract (ibidem, p. 169) ${ }^{37}$. There is, however, a broad discretionary power of the court to decide on that matter (Lenoir, Plankensteiner and Truffier, 2015, p. 129).

34 Case Lectiel v. France Telecom, judgment of the Supreme Court of 23.03.2010.

35 Case Subiteo v. France Télécom, judgment of the Supreme Court, 25.03.2014.

36 Council Regulation (EC) No. 1/2003 of 16 December 2002 on the implementation of the rules on competition laid down in Articles 81 and 82 of the Treaty (OJ L 1, 04.01.2003, p. 1).

37 See also e.g. Paris Court of Appeal, 16.11.2011, No. 09/16817. 


\section{Lithuania}

Lithuania is a place where the development of private antitrust enforcement is still almost unnoticeable, especially in comparison with the most advanced European Member States. This situation has not changed from the time when Lithuania joined the EU on 1 May 2004 (Gumbis, Juonys and Keserauskas, 2004, p. 1; Gudziunas, Audzevicius and Kozubowska, 2014, p. 93). Very few private cases are brought before Lithuanian courts based on antitrust infringements. However, this trend seems to be changing towards a growth of private enforcement including both the private as well as the public sector (ibidem).

A relatively small number of private antitrust litigations does not mean that there is no legal basis for such enforcement model. On the contrary, especially since the new Lithuanian competition law came into force (Gumbis, Juonys and Keserauskas, 2004, p. 1; Stanikunas and Burinskas, 2015, p. 239) ${ }^{38}$, the latter has become, together with Lithuania's civil law, the legal grounds for such complaints. Briefly speaking, the legal framework of tortious liability is similar to most European legal systems (ibidem). Furthermore, the claimant can bring private actions based on a breach of national competition law as well as EU competition rules seeking compensation for damages or the invalidity of an agreement for antitrust reasons (Gudziunas, Audzevicius and Kozubowska, 2014, p. 93).

The main legal ground for private antitrust enforcement can be found in Article 43 of Lithuania's Law on Competition which stipulates, that "economic entities that violate this Law must compensate damage caused to other economic entities or natural and legal person (...)" (Stanikunas and Burinskas, 2015, p. 243). The following Article 47 permits two types of actions: on the termination of illegal activities or on the compensation for damage caused by an antitrust infringement (ibidem). Based on that general rules, in private antitrust enforcement cases, general civil rules apply, mainly tort law, but contract-based antitrust complaints are admissible too. According to Articles 6.245-6.249 of the Lithuanian Civil Code, the plaintiff who sues the wrongdoer must thus prove: the unlawful act, damages, causal link and fault. The latter is considered as an intentional act or negligence with reference to objective criteria. The unlawful act includes a rebuttable presumption of fault, meaning that the defendant can refute the presumption proving otherwise (ibidem, p. 244; Gumbis, Juonys and Keserauskas, 2004, p. 3). In case of contractual liability, this principle is even stricter because the non-performing party can

38 Competition Law of Republic of Lithuania, VZ no. VIII-1099 adopted by the Parliament on 23.03.1999. 
escape liability only if force majeure is established (ibidem, p. 3), which can be considered as a strict liability principle.

With respect to the burden of proof, in order to succeed, the claimant must prove all of the aforementioned elements constituting civil liability, except fault, which is presumed once an unlawful act is proven. Requirements concerning the standard of proof are met when there are no reasonable doubts as to whether the available evidence is substantial, relevant and admissible (ibidem, p. 4). This is based on the balance of probabilities (Gudziunas, Audzevicius and Kozubowska, 2014, p. 95), while some say that it is even more than that but less than certainty (Gumbis, Juonys and Keserauskas, 2004, p. 4). As a result, the standard of the burden of proof is seen to be a deterrent to private enforcement in Lithuania, in particular due to the difficulty in proving attributable loss (Stanikunas and Burinskas, 2015, p. 246). It must be noted in relation to follow-on cases that a decision of the Lithuanian NCA has specific evidential (probative) value, as do its opinions in private antitrust cases. Both decisions and opinions have prima facie value in relation to the unlawful act, which means that the defendant can disprove them (Gumbis, Juonys and Keserauskas, 2004, p. 6; Gudziunas, Audzevicius and Kozubowska, 2014, p. 95). This rule reasonably applies to the decisions issued by NCAs from other Member States. However, it does not arise directly from Lithuanian law (Gumbis, Juonys and Keserauskas, 2004, p. 6; Stanikunas and Burinskas, 2015, p. 245).

\section{Principle of liability and the effectiveness of private antitrust enforcement}

Bearing in mind the relation between EU law and national laws discussed in part II of this paper and the short review included in part IV, it is now time to formulate some conclusions concerning the presumed interplay between the principle of civil liability in the given legal system and the development of its private antitrust enforcement. This issue is of interest at least for two reasons. First, the main goal of the Damages Directive is to strengthen, or even to trigger the private enforcement model in those States where the EC belies it to be underdeveloped, or even not developed at all. The principle of liability can play here an important role as the focal element of civil liability. Second, as mentioned in part I, the principle of liability was part of the discussions on the optimal manner of implementing the Damages Directive in Poland. In fact, it is still being debated, even if its shape has preliminarily been decided upon during the reconciliation conference held at the Ministry 
of Justice. Since the drafters of the forthcoming Polish law continue to keep an eye on the effectiveness factor, it is worth knowing if there really is a relationship between the development of private antitrust enforcement and the principle of liability. Although the following conclusions are not based on an in-depth analysis of the assessed legal systems, the available data makes it undoubtedly possible to formulate some notion about this relationship.

Looking at the above seven countries from a statistical point of view, it is noticeable that civil liability in case of tort is based on fault (with variations with respect to presumptions, prima facie evidence and the burden of proof) in almost all of them, except the UK. Contractual liability is to some extent stricter than torts, but roughly speaking it is also fault-based. Still, contractual liability seems often to be underestimated as a legal basis for private antitrust enforcement actions. There are thus three main conditions of liability based on antitrust infringements: (1) the breach of competition law including fault (even if presumed), (2) damage and its quantum and, (3) a causal link between damage and the infringement. It is worth noting that those conditions are common not only for European countries but also for those outside Europe such as Korea or China, with exception, inter alia, of Japan where it is based on a strict liability rule ${ }^{39}$.

In the vast majority of countries, this time including the UK, decisions issued by NCAs as well as of the EC have binding force in private antitrust litigations when it comes to the antitrust infringement at hand. In follow-on cases therefore, fault does not play any role unless the above mentioned decisions have "merely" prima facie evidential value. Then the defendant can prove the case to the contrary, in particular that his behaviour does not imply fault in any form (neither intended nor by negligence). Undoubtedly, in countries where the decisions of the authorities have binding force before the courts as regards to the antitrust infringement - where proving the contrary by the defendant is not admissible - the plaintiff is in an advantageous position from the very outset of the civil proceedings.

The liability principle exists in various combinations with the burden of proof and presumptions. This brings about a situation where even in faultbased liability, it is not the complainant that must provide evidences of the faulty act of the defendant, but the defendant must instead prove that he was not at fault, if he wants to successfully dismiss the plaintiff's complaint. There is no single, universal model of civil liability in private antitrust enforcement in the analysed European countries since a universal model of civil liability

39 See report drafted by the OECD, Relationship between public and private antitrust enforcement, 11.06.2015, p. 8-12 (retrieved from: http://www.oecd.org/officialdocuments/public displaydocumentpdf/? cote $=\mathrm{DAF} / \mathrm{COMP} / \mathrm{WP} 3 / \mathrm{WD}$ (2015)14\&docLanguage $=$ En, 02.09.2016). 
does not exists at all (see remarks regarding the harmonization of private law in the EU and draft of regulation on common European sales law: Wolski, 2012a; Wolski, 2012b; Wolski 2012c). However, in the vast majority of States, private antitrust actions are being brought based on general rules of civil liability dominated by fault-based liability with its modifications.

While the fault-based model of liability in private antitrust enforcement prevails among the aforementioned countries, the development level of antitrust litigations is not equal among them. Some countries, like the UK, the Netherlands or Germany, have great degree of experience in this regard. Special emphasis has to be placed here on the UK and its Competition Appeal Tribunal, which has become the focal point of private antitrust litigations in Europe in recent years. In spite of the conclusions arising from the EC's reports on the condition of private enforcement in Europe, Holland and Germany do not lag behind with their level of development. Austria seems to be mid-range in its development in terms of antitrust litigations, while France and Italy are somewhat less advanced, but showing notable potential for the future. Lithuania and Poland, the latter as the eighth state under analysis here with a fault-based liability and a presumption of fault in contractual liability, are located at the end of the spectrum with a marginal number of private enforcement cases.

Is it possible to formulate even a rough conclusion based on this brief analysis with respect to the interplay between the principle of liability and the status of the development of private antitrust enforcement in these EU Member States? Yes, it is, in particular because the chosen eight countries stretch across the whole spectrum of the EU when it comes to both antitrust enforcement and economic developments. This makes them a representative group, at least for the purposes of this article. Even at first glance, without having analysed the exact number of private antitrust enforcement cases, it is noticeable that there is no specific link between the principle of liability and the status of private enforcement in particular countries. In truth, the UK has the most developed private enforcement system in the EU while employing a strict liability principle instead of the more usual fault-based liability. Yet the exception of the UK is actually not an exception at all if we compare its achievements with those of Germany or the Netherlands, which are less impressive but of comparable scale (see in particular German development in: Peyer, 2010). Moreover, Britain's popularity as the centre of antitrust litigations, as well as its very successful track record in this area, seem to be mainly due to the creation of a specialized, professional, efficient court that has an economic background - the Competition Appeal Tribunal in London. Since in the other countries with fault-based liability (unlike the strict liability in the UK) private antitrust enforcement is far more than 
appreciable, it is impossible to find any causal link between those principles and the number of private antitrust cases or successful private enforcement. In Lithuania, which has a similar legal framework for antitrust litigations to France, such enforcement actually does not exist. It can be said that the reason for such difference between France and Lithuania lies in a huge disproportion in the economies of both countries and their respective size too. Yet Poland, a country comparable in size to France which also has a successful and developed economy, is at a similar stage when it comes to its private antitrust enforcement than Lithuania. Furthermore, over the past twenty years, the Polish NCA issued a number of decisions on competition law infringements ${ }^{40}$ as well as imposed a huge amount of fines based on Article 6 and Article 9 of the Polish Act on Competition and Consumer Protection ${ }^{41}$. In other words, public enforcement of competition law in Poland is very much active. Unlike its public legacy in antitrust enforcement, it did not however, entail the same number of private cases, which remain until now almost unnoticeable.

All the above facts strongly suggest that there is no actual interplay between the principle of liability and the stage of the development of private antitrust litigations in a given country. This conclusion has significance in the context of the interplay between EU and national laws discussed in part II in light of the principles of efficiency and equivalence. It is thus fair to say that what is more important for efficiency is better awareness of the private antitrust enforcement model among undertakings as well as an efficient, specialized judiciary disposing of an economic background competent to deal with private enforcement cases. The binding force of decisions issued by competition authorities plays a supportive role in this context also. Those are the key factors determining success in the development of private enforcement.

\section{Conclusions}

As emphasized at the beginning of this paper, this discussion should be considered against the background of the implementation works concerning the Damages Directive into the Polish legal system. The final part of this paper should thus be devoted to this very issue. Bearing in mind the results of the analysis conducted in part IV, it turns out that the fierce discussions surrounding

40 See website of the Polish competition authority https://www.uokik.gov.pl/.

41 Consolidated text Journal of Laws 2015, item 184 as amended. Article 6 and 9 PCCPA are similar to Article 101 and 102 TFEU. 
the principle of liability that took place in the course of the implementation works on the Damages Directive overestimated the implications of this issue. The effectiveness of antitrust litigations depends to a very small extent on the type of the liability principle used - in other words, whether it is fault-based or strict liability. Such effectiveness and, as a result, the level of the development of private antitrust enforcement is far more affected by the burden of proof and presumptions. What proved most relevant is the binding power of decisions issued by competition authorities (NCAs and the EC) confirming an antitrust breach by defendant in the civil case. The latter factor seems to be key for successful antitrust litigations and is also the reason why follow-on actions supersede stand-alone cases. On the other hand, and by contrast to common opinion, stand-alone cases are more than an exception.

All in all, the solution preliminarily reached in Poland seems to be quite reasonable - fault-based liability but with a rebuttable presumption of fault of the defendant. This approach is in line with liability rules in private antitrust enforcement adopted in the vast majority of the analysed EU Member States, in particular Germany or the Netherlands, which both have great experiences in antitrust litigations.

Bearing in mind effective private antitrust enforcement and its relationship to the principle of liability, it is also worth noting that setting this goal in the Damages Directive in the context of damages actions, the EC presumably failed and for two reasons. First, compensation as one of the main goals of private antitrust enforcement does not work at all because the true victims of anticompetitive behaviour, usually consumers, are "too numerous and too remote from violation to locate and compensate" (Crane, 2010, p. 677). This inevitably brings about the second mistake of the Commission. The EC focused overly on the compensatory role of the Damages Directive and on the measures meant to help victims get compensation such as: the concept of overcharge, direct and indirect purchaser, limitation period, passing-on defence, calculation of damage etc. By so doing, the EC almost completely disregarded a number of more important obstacles on the path to effective private enforcement. According to commentators these include issues such as legal costs, cost shifting or claim aggregation (Peyer, 2015, p. 29). For obvious reasons it is too late now to rethink the main goals and measures of the Directive. There is still time, however, to analyse why private antitrust enforcement works in some States, despite the lack of measures included in the Damages Directive, but it does not in others. This is even more interesting because, as can be seen from the review in this article, both successful and unsuccessful States have almost identical legal regimes for antitrust litigations. 


\section{Literature}

Buntscheck, M. and Stichweh, H. (2015). Germany: Private Antitrust Litigation, The European Antitrust Review, 154-158.

Clough, M. and McDougall, A. (2004). United Kingdom. London: Ashurst. Retrieved from: http://ec.europa.eu/competition/antitrust/actionsdamages/national_reports/ united_kingdom_en.pdf (02.09.2016).

Crane, D.A. (2010). Optimizing Private Antitrust Enforcement, Vanderbilt Law Review, 63(2), 675-723.

Elsner, B., Zandler, D. and Kos, M. (2016). Austria. In: I. Knable Gotts (ed.), The Private Competition Enforcement Review. London: Law Business Research Ltd, 49-59.

Gudziunas, M., Audzevicius, R. and Kozubowska, B. (2014). Lithuania, Private Antitrust Litigation, 93-98.

Gumbis, J., Juonys, M. and Keserauskas, S. (2004). Lithuania. Vilnius: Lideika, Petrauskas, Valiūnas ir partneriai. Retrieved from: (http://ec.europa.eu/competition/antitrust/ actionsdamages/national_reports/lithuania_en.pdf (02.09.2016).

Havu, K. (2014). Fault in EU law based competition restriction damages cases, Maastricht European Private Law Institute Working Paper No. 2014/16, July 2016. Retrieved from: http://papers.ssrn.com/sol3/papers.cfm?abstract_id=2465912 (02.09.2016).

Jones, A. (2016). Private Enforcement of UE Competition Law: A Comparison with, and Lessons from, the US. A Dickson Poon Transnational Law Institute, King's College London, Research Paper Series, Paper No. 10/2016. Retrieved from: http://papers.ssrn. com/sol3/papers.cfm?abstract_id=2715796 (02.09.2016).

Jurkowska, A. (2008). Private Antitrust Enforcement - Case of Poland. Yearbook of Antitrust and Regulatory Studies, 1(1), 59-79.

Kuijpers, M., Tuinenga, S., Wiskin, S., Dietzel, K., Campbell, S., Fritzsche, A. (2015). Actions for Damages in the Netherlands, the United Kingdom, and Germany, Journal of European Competition Law \& Practice 6(2), 1-14. Retrieved from: https:// www.stibbe.com/ /media/03\%20news/publications/amsterdam/ stefan $\% 20$ tuinenga/ journal $\% 20$ of $\% 20$ european $\% 20$ competitionlaw $\% 20 \% 20$ practice-2015--jeclap-lpu 125. pdf (02.09.2016).

Leeflang, F. and Kuijper, M. (2013). Netherlands, Private Antitrust Litigation, 94-99. Retrieved from: http://www.boekel.com/media/617927/private_antitrust_litigation_in_ the_netherlands_-_2013.pdf (02.09.2016).

Lenoir, N., Plankensteiner, M. and Truffier, M. (2015). France: Private Antitrust Litigation, The European Antitrust Review, 127-133. Retrieved from: http://www. kramerlevin.com/files/Publication/a41298ed-1a62-4ff0-8cb4-fa825d8c08e7/Presentation/ PublicationAttachment/38d554af-0c20-47a3-b35b-fb2c51b7cc97/1408_GCR_Private\% 20Antitrust \%20Litigfation\%202015_French\%20Chapter_Private\%20Ënforcement.pdf (02.09.2016).

Monti, M. (2001). Effective Private Enforcement of EC Antitrust Law. Speech delivered at Sixth UE Competition Law and Policy Workshop, Florence. Retrieved from: europa. eu/rapid/press-release_SPEECH-01-258_en.pdf (02.09.2016).

Neumayr, F. and Ablasser-Neuhuber, A. (2016). Austria - Competition Litigation 2017, International Comparative Legal Guides Retrieved from: http://www.iclg.co.uk/practiceareas/competition-litigation/competition-litigation-2017/austria\# chaptercontent1. 
Peyer, S. (2010). Myths and Untold Stories - Private Antitrust Enforcement in Germany, University of East Anglia, Centre for Competition Policy, Working Paper 10-12. Retrieved from: https://ueaeprints.uea.ac.uk/29237/1/Peyer_-_Myths_and_Untold_Stories-Private_ Antitrust_Enforcement_in_Germany.pdf (02.09.2016).

Peyer, S. (2015). Compensation and the Damages Directive, University of East Anglia, Centre for Competition Policy, Working Paper 15-10. Retrieved from: http://competitionpolicy. ac.uk/documents/8158338/8368036/15-10+CCP+Working + Paper/78f92b0e-6f92-4538bca7-4f45e8de7b2b (02.09.2016).

Safjan, M. (2008). In: K. Pietrzykowski (ed.), Kodeks cywilny. Komentarz. Tom I. Warszawa: $\mathrm{CH}$ Beck.

Siragusa, M., D’Ostuni, M. and Rizza, C. (2014), Italy, Private Antitrust Litigation, 79-87. Retrieved from: https://www.clearygottlieb.com/ /media/cgsh/files/other-pdfs/privateantitrust-litigation-italy-2014.pdf (02.09.2016).

Stanikunas, R.A. and Burinskas, A. (2015). The Interaction of Public and Private Enforcement of Competition Law in Lithuania. Yearbook of Antitrust and Regulatory Studies, 8(12), 237-257.

Stefanicki, R. (2014). Prywatnoprawne środki dochodzenia roszczeń z tytutu naruszenia regut konkurencji. Warszawa: $\mathrm{CH}$ Beck.

Tardella, E. and Maggiore, M. (2004). Italy. Milan: Ashurst. Retrieved from: http://ec.europa. eu/competition/antitrust/actionsdamages/national_reports/italy_en.pdf (02.09.2016).

Thill-Tayara, M. and Giner Asins, M. (2015). France. In: I. Knable Gotts (ed.), The Private Competition Enforcement Review. London: Law Business Research Ltd, 170-184.

VerLoren van Themaat, W., Hettema, J. and Buruma, H. (2004). Netherlands. Brussels: Ashurst. Retrieved from: http://ec.europa.eu/competition/antitrust/actionsdamages/ national_reports/netherlands_en.pdf (02.09.2016).

Wach, K., Ëpping, M., Zinsmeister, U. and Bonacker, E. (2004). Germany. München: Ashurst. Retrieved from: http://ec.europa.eu/competition/antitrust/actionsdamages/ national_reports/germany_en.pdf (02.09.2016).

Waterson, M. (2010). Beer - the ties that bind, Warwick Economic Research Papers, University of Warwick, Paper No. 930. Retrieved from: https://www2.warwick.ac.uk/fac/ soc/economics/research/workingpapers/2010/twerp_930.pdf (02.09.2016).

Wollmann, H. and Prisker, A. (2004). Austria. Wien: Schönherr Rechtsanwälte OEG. Retrieved from: http://ec.europa.eu/competition/antitrust/actionsdamages/national_ reports/austria_en.pdf (02.09.2016).

Wolski, D. (2012a). Harmonizacja a ujednolicenie norm prawa prywatnego - wybrane zagadnienia. In: C. Mik (ed.), Unia Europejska: zjednoczeni w różnorodności. Warszawa: Wydawnictwo Sejmowe, 315-346.

Wolski, D. (2012b). Projekt rozporządzenia Parlamentu Europejskiego i Rady w sprawie wspólnego europejskiego prawa sprzedaży, Kwartalnik Prawa Prywatnego XXI(3), 809-827.

Wolski, D. (2012c). Wątpliwości dotyczące podstaw traktatowych projektu rozporządzenia w sprawie europejskiego prawa sprzedaży, Problemy Wspótczesnego Prawa Międzynarodowego, Europejskiego i Porównawczego, X, 138-152.

Wolski, D. (2016). Zasada i przesłanki odpowiedzialności odszkodowawczej, ustalenie wysokości szkody, przerzucanie nadmiernych obciążeń. In: D. Wolski, A. Piszcz (eds), Dochodzenie przed sadem polskim roszczeń odszkodowawczych z tytułu naruszenia regut konkurencji. Warszawa: Wydawnictwo Naukowe Wydziału Zarządzania Uniwersytetu Warszawskiego, 39-62. 